\title{
Dark Outside
}

Gerard Hodgins

Long Kesh

When darkness falls a mantle of blackest velvet covers our world of impenetrable darkness

From which iridescent lights, orange and yellow poke fingers in the sky,

Fingers that soon disappear in the inky blackness but nevertheless keep illuminated

The wall and wire, and steel and stone while black cadaverous mechanical beasts hover overhead in monotonous hum;

Predators hunting for unsuspecting prey trying to escape the night.

When darkness falls the lights come on in defiance of nature's law, Nothing but light may surround our ignoble prison town;

Least we miss the look of gloom which flickers across each ashen face every once in a while like a wicked malevolent smile;

For the chained will always strain to be free and not surrounded by walls, For walls can grind the spirit down unless the spirit soon learns how to build walls of its own to fight for survival on its own holy ground. 